\title{
Intention of Hospital Managers in Implementing the Balanced Scorecard
}

\author{
Aglita Janis Rupita S*, Heru Kurnianto Tjahjono** \\ * Correspondent Author: Sektiriani26@gmail.com \\ * Master of Hospital Management, Universitas Muhammadiyah Yogyakarta, Yogyakarta, Indonesia \\ ** Master of Management, Universitas Muhammadiyah Yogyakarta, yogyakarta,Indonesia
}

\section{N D E X I N G}

Keywords:

Theory Planned

Behaviour;

Balanced Scorecard;

Intention;

Kata kunci:

Planned Bheviour Teori;

Balanced Scorecard;

Intensi;

\begin{abstract}
A B S T R AC T
Achieving the implementation of a hospital's vision and mission depends on the strategies that used and the management of human resources. Balanced scorecard (BSC) is one of the strategic tools that are in great demand today to be applied in the health sector. The interest or intention in implementing of BSC depends on individual attitudinal factors, subjective norms and behavioral controls that refer to Planned Behavior (TPB). The aim of this study is to determine the intention of hospital managers in implementing the balanced scorecard. This type of research is quantitative descriptive with a cross sectional approach and the sampling technique used purposive sampling. The methods of data collecting used questionnaires, interviewed and analyzed by multiple linear regression. The results of the 90 samples showed an influence on attitudinal variables, subjective norms and simultaneous behavioral control as indicated by $\mathrm{Sig}=0,000$. While partially attitudinal variables (Sig = $0.029<0.05)$, subjective norm $(\mathrm{Sig}=0.011<0.05)$ and behaviour control have effect on intention (Sig $=0.036<0.05)$.
\end{abstract}

Pencapaian pelaksanaan visi misi sebuah rumah sakit bergantung pada strategi yang dipakai dan pengelolaan sumber daya manusia. Balanced scorecard (BSC) menjadi salah satu alat strategi yang sudah banyak diminati saat ini untuk diterapkan di sektor kesehatan. Minat atau niat dalam melaksanakan BSC bergantung pada faktor sikap individu, norma subjektif dan kontrol perilaku yang mengacu pada Theory Planned Behaviour (TPB). Tujuan penelitian ini adalah untuk mengetahui intensi manajer rumah sakit dalam mengimplementasikan balanced scorecard. Jenis penelitian ini adalah kuantitatif deskriptif dengan pendekatan cross sectional dan teknik pengambilan sampel menggunakan purposive sampling. Metode pengumpulan data menggunakan kuesioner dan wawancara serta dianalisis dengan regresi linier berganda. Hasil penelitian dari 90 sampel menunjukan adanya pengaruh pada variabel sikap, norma subjektif dan kontrol perilaku terhadap intensi secara simultan yang ditunjukan dengan nilai Sig=0,000. Sedangkan secara parsial variabel sikap (Sig=0,029<0,05), norma subjektif (Sig=0,011<0,05) dan kontrol perilaku $($ Sig=0.036<0.05) yang memiliki pengaruh terhadap intensi pada manajer.

(C) 2018 JMMR. All rights reserved

Article history: Received 2018-Dec-14; Revised 2018-Dec-16; Accepted 2018-Dec-17

\section{INTRODUCTION}

Progress oriented of hospitals will certainly develop strategies to be able to realize the vision and mission that has been set. Determination of strategies for a hospital is an important thing because the increasing number of competitors requires hospitals to compete, survive, and maintain patient loyalty for the continuity of the hospital itself ${ }^{ \pm}$. Strategy management in the hospital sector used to help managers to predict the future with various possible events, fostering commitment of each employee in the hospital, and creating a culture of mutual support between professions and employees in realizing hopes for hospitals in future 2 . The strategy carried out by the hospital is to improve the quality and standards of each health service so that good quality service is created. Good service can provide satisfaction to patients. This is in accordance with the opinions expressed by You et $\mathrm{al}^{3}$. Where there is a significant relationship between service quality and patient satisfaction level.

The cause of failure in hospital services is related to the implementation of strategies taken by the hospital. One of the main reasons for the failure of the implementation of the strategy was the lack of an effective management control system within the organization or company ${ }^{4}$. Management control tailored to the conditions of the organization or company is very important for the implementation of effective strategies ${ }^{5}$. The use and planning of strategies that are still considered not good 
enough can be done to develop the strategy as an evaluation material in the years ahead so that the hospital has the opportunity to enter market share. The development of a strategy that is considered less will have an impact on the implementation of the hospital because of the programs, procedures and budgets that the hospital has are not in accordance with the conditions at that time ${ }^{-6}$. In this case, the Balanced Scorecard (BSC) serves as a comprehensive strategic control tool to achieve the desired strategic results.

Since being published by Kaplan and Norton in 1992, the use of the Balanced Scorecard (BSC) has developed as a major strategic management system that is internationally recognized. The use of this system is used in various sectors of organizations such as profit and non-profit institutions of all sizes, types and interests. Indonesia has now begun to be able to present the idea of using BSC as evidenced by existing BSC books. The definition of BSC is strategic planning and management systems that are widely applied to organizations regardless of the size or type of business in which this concept can facilitate the development and review of the organization's vision and strategy, provide methods for harmonizing the organization's business activities with that strategy, and improve internal and external communication of the organization, and enable the organization to monitor its performance against its strategic goals ${ }^{7}$. This BSC shows that we must look at organizations from four perspectives, financial, customer, internal business, learning and growth perspectives that are interrelated ${ }^{9}$. The usefulness of this method is to help make decisions both individually and in teams, identify opportunities or threats, monitor corrective actions, and review the suitability of the objectives set. The concept of BSC can be one of the management strategies implemented in hospitals.

BSC is not only used for strategic management at the organizational level, but has also been used in the health sector to evaluate health programs, quality of care and quality improvement services, accreditation, clinical pathways, and performance measurement ${ }^{-}$. Hospitals are one sector that has many elements and has unique challenges to face. Some challenges that may be faced by hospitals are the diversity of stakeholders, the availability of resources and funds, facing demands from the government to improve service quality and patient outcomes, increasing prevalence of chronic diseases, and medical discipline ${ }^{7}$.

The application of BSC in hospitals is very useful ${ }^{10}$. Results of research conducted by Beatriz, Sanchez, Maria, Pires, and Broccardo at St. Vincent in 2010-2012 showed an increase in patient satisfaction ( $88 \%$ to $96 \%)$, an increase in the percentage of patients ( $43 \%$ to $68 \%)$, an increase in the percentage of patients who were considered risky $(40 \%$ to $90 \%)$, decreased incidence of MRSA (methicillin- resistant to staphylococcus aureus), decreased fall incidence and treatment incidents, decreased rates of hospitalization, vacancy rates and turnover rates. In addition, the benefits of BSC in the health sector were improvement in quality of care and care outcomes for patients because it focuses on patients, increased management and medical accountability with clear goals, improved communication, and stimulating new discussion between doctors and management about vision and strategy. The benefits and benefits that the hospital gets when implementing the BSC system should be communicated to the managerial ranks in order to be able to make hospitals oriented to full service $\stackrel{11}{-}$.

Support from management regarding strategies brings aspects of beliefs, intentions, and individual perceptions of employees that leaders will support the implementation of strategies that have been made. Intentions are anticipated signals in certain situations with preconceived beliefs for specific behavioral choices or which specific behaviors will be applied so that goals can be achieved $\stackrel{12}{ }$. Intention is also sometimes seen as a kind of strong determination to achieve something. The greater one's intention, then the possibility of appearing to behave will be high and vice versa.

Implementation of the BSC apart from the direct determinants of intention and behavior, with the Theory of Planned Behavior proposed by Ajzen also identifies that intention is influenced by individual attitudes where attitude towards behavior is an evaluation that supports or does not support a person to perform the behavior in question, subjective norms where there is social pressure to do or not do the desired treatment, and behavioral control where the individual's perception of the ease of treatment is carried out . In addition to the intention factor, several factors that motivate managers to implement $\mathrm{BSC}$ as an innovative strategy management technique that is adherence to new forms of information where management is open to innovation, control systems are related to action, personal and cultural control, then an evaluation system is the way managers evaluate their staff.

Intention can accurately predict various behavioral tendencies. Based on the theory of planned behavior, intention is a function of the three main determinants, first is the personal factor of the individual, second is the social influence, and the third is related to individual control. Based on the description above the notion of intention in 
this study is the tendency of a person to perform certain behaviors either consciously or not. Identify the level of specificity in targets, situations, and time dimensions is relatively easy, but the dimensions of behavior are relatively more difficult to identify. The best measurement of intention in order to predict behavior is to include the four aspects of intention, namely behavior, target, situation, and time $\stackrel{14}{ }$.

TPB is an extension of Theory Reasoned Action (TRA). TPB uses attitudes, subjective norms and behavioral controls that are felt to predict intentions with relatively high accuracy. This theory assumes that one's intentions, when combined with perceptions of behavioral control, will help predict behavior with higher accuracy than the previous model ${ }^{16}$. Individual attitude, this refers to the extent to which a person has positive or negative feelings from his behavior. This requires consideration of the results of the conduct of behavior. We learn to like behaviors that we believe have very desirable consequences and we form unprofitable attitudes towards the behaviors which we associate with mostly unwanted consequences ${ }^{14}$. In particular, subjective value results contribute to attitudes comparable to the power of trust.

Subjective norms, formed by normative beliefs (the most important individual beliefs) about whether certain groups of important people (such as coworkers, superiors, teachers, etc.) think that they must do behavior. The construction of subjective norms is normative commitment and social influence. Normative commitment as an obligation or social pressure felt to behave according to organizational expectations. Defines social influence as a broader term that includes subjective norms, social factors, and images.

Behavior Control, can affect behavior directly or indirectly through behavioral intentions. Behavior control is expected to rise the behavior when there is an agreement between the perception of control and control of someone as long as the behavior is carried out. The perceived level of control must strengthen one's desire to conduct behavior and increase business and perseverance. Therefor perceived behavioral control can influence behavior indirectly with its influence on intention. The more individuals feel a lot of supporting factors and a few inhibiting factors to be able to perform a behavior, the greater the control they feel for the behavior and vice versa, the fewer individuals feel the supporting factors and many inhibiting factors to perform a behavior tend to perceive themselves difficult to do this behavior $\stackrel{14}{ }$. The purpose of the study was to determine the intention of hospital in implementing balanced scorecards.

\section{RESEARCH METHOD}

The research was a quantitative descriptive study with a cross sectional approach conducted at PKU Muhammadiyah Bantul Hospital and Postgraduate Masters in Hospital Management at the University of Muhammadiyah Yogyakarta and University of Gadjah Mada in March 2018-April 2018. Sampling used total sampling technique that is adjusted to the inclusion criteria so that 90 respondents were obtained. The data in this study were obtained using a questionnaire with Likert scale measurements and interviews. The data obtained were analyzed using multiple linear regression.

Inclusion criteria of the respondents are as follows: a. UMY MMR students who are located as managers (top, middle, or low) in the hospital where they work. b. UGM MMR students who are located as managers (top, middle, or low) in the hospital where they work. c. Managers working in hospitals that have used the Balanced Scorecard. d. 25-52 years old. e. Know about the Balanced Scorecard. f. Willing to be a respondent. The number of samples in this study were 95 respondents consisting of 42 respondents from PKU Muhammadiyah Bantul Hospital, 35 MMR students and 13 UGM MMR students.

Operational definition of individual's attitude is the manager's belief about the benefits felt when implementing the Balanced Scorecard. Subjective normative means the beliefs and desires of managers to use the Balanced Scorecard that comes from the advice of coworkers, leaders, and information technology, and academics. Behavioral control means managers' perceptions of the ease or difficulty in implementing the Balanced Scorecard. The scale of the data used by researchers is the ordinal data scale. Based on TPB, (Ajzen, 1991) in (Greaves et al., 2013) Ajzen revealed the intention to behave was influenced by attitude variables (attitude / AAct), subjective norms (subjective norm / $\mathrm{SN}$ ), and behavioral control (Behavior Control / BC) $\stackrel{14}{\text {. }}$

Attitudes are defined as feelings of support or favor (favorableness) or feelings of not supporting or unfavorableness of an object to be addressed. This feeling arises from the existence of an individual evaluation of the belief in the results obtained from that particular behavior. Research conducted indicates that attitudes toward behavior have a positive and significant influence on intention . Based on the above considerations, the following hypotheses are formulated: 
H1: The intention of the $\mathrm{X}$ and millennial generation hospital managers to implement the Balanced Scorecard is influenced by attitudes toward behavior.

The second variable of the TPB model is subjective norms which are defined as the influence of the people around who are referenced $\frac{19}{}$. Subjective norms refer to individual perceptions of whether certain individuals or certain groups agree or disagree with their behavior, and the motivation given by them to individuals for certain behaviors. The people around who are referenced are for example friends, family, or leaders. The results of research show that subjective norms, namely the perceptions of others such as peers and family, have a positive and significant effect on intention $\frac{15}{-}$. Based on the above considerations, the following hypotheses are formulated:

$\mathrm{H} 2$ : The intention of hospital managers of generation $\mathrm{X}$ and millennial in implementing the Balanced Scorecard is influenced by subjective norms.

Behavior control refers to a person's perception of the difficulty or not of carrying out the desired behavior, related to the belief in whether or not there are resources and opportunities that needed to realize certain behaviors ${ }^{16}$. There are two aspects which considered, first, how much the person has control of a behavior (controllability), and second, how confident that person feels able to perform a behavior (self-efficacy). Research states that PBC affects the intention to behave $\mathrm{e}^{15}$. Based on the considerations above, the following hypotheses are formulated:

H3: The intention of the $X$ and millennial hospital managers generation in implementing the Balanced Scorecard is influenced by behavioral control.

Intention is determined by three kinds of considerations. The first consideration is called behavioral beliefs and refers to positive perceptions or negative consequences of behavior and subjective values of evaluating these consequences. The second consideration must be carried out with the hope and behfavior felt by the individual as an important reference, combined with the person's motivation to comply with the intended reference. The third consideration is the control belief that is related to the perceived existence of factors that can affect a person's ability to behave like that. The results of the study state that there are influences on attitudes, subjective norms, and behavioral controls on intention to behave $\stackrel{20}{ }$. Based on the above considerations, the following hypotheses are formulated:

$\mathrm{H} 4$ : The intention of hospital managers of generation $\mathrm{X}$ and millennial in implementing the Balanced Scorecard is influenced by attitudes toward behavior, subjective norms, and behavioral control.

\section{RESULT AND DISCUSSION}

\section{Result}

Respondents in this study were managers who were based in low, middle, and top management at PKU Muhammadiyah Bantul Hospital, students who were based as managers in the Universitas Muhammadiyah Yogyakarta and Master of Hospital Management classes of Universitas Gadjah Mada. The number of respondents in this study were 90 respondents.

Tabel 1. Distribution of Frequency of Demographic Characteristics of Respondents in PKU Muhammadiyah Bantul Hospital, MMR UMY and UGM (N = 90)

\begin{tabular}{|c|c|c|}
\hline caracteristic Responden & $\begin{array}{l}\text { Frekuensi } \\
\text { (f) }\end{array}$ & $\begin{array}{c}\text { Persentase } \\
(\%)\end{array}$ \\
\hline \multicolumn{3}{|l|}{ Age } \\
\hline $38-53$ thn & 45 & 50,0 \\
\hline $25-37$ thn & 45 & 50,0 \\
\hline \multicolumn{3}{|l|}{ Gender } \\
\hline Perempuan & 47 & 52,2 \\
\hline Laki-Laki & 43 & 47,8 \\
\hline \multicolumn{3}{|l|}{ Last Education } \\
\hline Diploma & 7 & 7,4 \\
\hline Sarjana & 73 & 81,1 \\
\hline Master & 10 & 11,1 \\
\hline Doktor & 0 & 0 \\
\hline \multicolumn{3}{|l|}{ Position } \\
\hline Top Management & 17 & 18,9 \\
\hline Middle Management & 42 & 46,7 \\
\hline Low Management & 31 & 34,4 \\
\hline \multicolumn{3}{|l|}{ Length Working } \\
\hline$<10$ tahun & 41 & 45,6 \\
\hline$>10$ tahun & 49 & 54,4 \\
\hline
\end{tabular}

Source: Primer Data (2018)

Characteristics of 90 respondents at most female gender 47 people $(52.6 \%)$ with the last education with undergraduate education, 73 people $(81.1 \%)$ who are located in middle management, 42 people $(46.7 \%)$ and the length of work at the hospital $>10$ years as many as 49 people $(54.4 \%)$. 
Tabel 2. Frequency Distribution of Attitudes in Managers' Behavior $(\mathbf{N}=90)$

\begin{tabular}{lcc}
\hline & Frekuensi (f) & Persentase (\%) \\
\hline Tinggi & 73 & 82,3 \\
Sedang & 17 & 17,7 \\
Rendah & 0 & 0 \\
Total & 90 & 100,0 \\
\hline
\end{tabular}

Source: Primer Data (2018)

In table 2 shows more than three per four respondents have high behavioral attitudes.

Tabel 3. Frequency Distribution of Attitudes in Managers' Subjective Norm $(\mathbf{N}=90)$

\begin{tabular}{lcc}
\hline & Frekuensi (f) & Persentase (\%) \\
\hline Tinggi & 36 & 43,2 \\
Sedang & 52 & 54,7 \\
Rendah & 2 & 2,1 \\
Total & 90 & 100,0 \\
\hline
\end{tabular}

Source: Primer Data (2018)

In the distribution of subjective norms, more than half of respondents have subjective norms with moderate categories

Tabel 4. Frequency Distribution of Attitudes in Managers' Behaviour Control $(\mathbf{N}=90)$

\begin{tabular}{lcc}
\hline & Frekuensi (f) & Persentase (\%) \\
\hline Tinggi & 41 & 47,4 \\
Sedang & 48 & 51,6 \\
Rendah & 1 & 1,1 \\
Total & 90 & 100,0 \\
\hline Source: Primer
\end{tabular}

Based on table 4 , it was found that more than $50 \%$ of respondents had behavioral control in the medium category.
Tabel 5. Frequency Distribution of Attitudes in Managers' Intention ( $\mathbf{N}=\mathbf{9 0})$

\begin{tabular}{lcc}
\hline & Frekuensi (f) & Persentase (\%) \\
\hline Tinggi & 56 & 52,6 \\
Sedang & 44 & 46,3 \\
Rendah & 1 & 1,1 \\
Total & 90 & 100,0 \\
\hline
\end{tabular}

Source: Primer Data (2018)

In table 5, it is found that as many as 50\% of respondents fall into the high category of intentions.

In the table above, it can be seen that $\mathrm{F}$ test obtained $\mathrm{F}$ count value of 23,883 with probability $(\mathrm{p}=0.000)$. This shows that $\mathrm{F}$ count $(23,883)>\mathrm{F}$ table $(17,257)$. That is, Ho is rejected, which means that attitude, subjective norm and behaviour control together have a positive and significant effect on the dependent variable of intentions manager.

Tabel 6. The Results of $F$ Test Manager Intention in Implementing the Balanced Scorecard

\begin{tabular}{cccccc}
\hline Model & $\begin{array}{c}\text { Sum of } \\
\text { Square } \\
\text { s }\end{array}$ & $\begin{array}{c}\text { d } \\
\mathbf{f}\end{array}$ & $\begin{array}{c}\text { Mean } \\
\text { Square }\end{array}$ & F & Sig. \\
\hline $\begin{array}{c}\text { Regress } \\
\text { ion }\end{array}$ & $\begin{array}{c}63,63 \\
1\end{array}$ & 3 & 21,210 & 14,217 &, $000^{\mathrm{b}}$
\end{tabular}

Source: Primer Data (2018)

Attitude variable (X1) with a value of $t$ count 2.226 and the value is greater than t table (2.102) with a significant level of 0.029 (smaller than 0.05). Ho refused Ha accepted. Based on this, it can be concluded that the attitude variable is partially positive and significant towards the intention (Y), this means giving a positive and significant contribution to the intention of manager. Subjective norm (X2) The value of $t$ count is 2.585 and is greater than $t$ table (2.102) with a significant level of 0.011 (smaller than 0.05).

Tabel 7. The Result of $t$ Test Manager Intention in Implementing the Balanced Scorecard

\begin{tabular}{|c|c|c|c|c|c|c|}
\hline & Model & B & Std. Error & $\begin{array}{c}\text { Standardized Coefficients } \\
\text { Beta }\end{array}$ & $\mathbf{t}$ & Sig. \\
\hline \multirow[t]{3}{*}{1} & (Constant) & .320 & 1.498 & & .214 & .831 \\
\hline & Attitude &. .118 & .053 & .240 & 2.226 & .029 \\
\hline & Behavior Control & .183 & .086 & .265 & 2.133 & .036 \\
\hline
\end{tabular}

Source: Primer Data (2018)

Ho is rejected and $\mathrm{Ha}$ is accepted, considering that it can be concluded that the subjective norm variables are partially positive and significant towards the intention of

manager $(\mathrm{Y})$ this contributes positively and significantly to the intention of managers in hospital. Behaviour control (X3) The value of $t$ count is 2.133 and is greater than $t$ table 
(2.102) with a significant level of 0.036 (smaller than 0.05). $\mathrm{Ho}$ is rejected and $\mathrm{Ha}$ is accepted, considering that it can be concluded that the behaviour control variables are partially positive and significant towards the intention of manager (Y) this contributes positively and significantly to the intention of managers in hospital.

\section{Discussion}

The results of this study indicate that there is a simultaneous influence between attitude variables, subjective norms and behavioral controls on the intentions managers. This is evidenced by the number value Sig. 0,000 in table 2. Individual attitudes, subjective norms and behavioral controls that appear consistently from managers are considered as positive predictors for forming intentions to implement the balanced scorecard. The results of the research put forward state that individual attitudes, subjective norms and behavioral control together explain the formation of intention by $59 \% \stackrel{21}{-}$.

Manager's intention in implementing the balanced scorecard is in the high category with a percentage of $50 \%$. High intentions from managers may be due to the success of the parts of the board of directors in introducing and conveying the intent and purpose of the implementation of this system as a whole. Personality factors and perceptions that are appropriate for managers can help to form intentions in implementing the balanced scorecard. The results of this study reveal that the most respondents are tenure of more than 10 years. This condition allows managers to be more focused on results in its work, given the success of the work is not only determined by the achievement of tasks that have been given to him but also to colleagues or employees who are under his leadership. Characteristics of ideal leaders is someone who can coordinate and who can be relied upon to work together $\underline{22}$.

The attitudes of individuals in this study are negative or positive feelings of managers in implementing a balanced scorecard, where managers learn to like behaviors that are believed to have highly desirable consequences and form unfavorable attitudes towards behaviors associated with mostly unwanted consequences. Attitude towards behavior is one of the determining variables and can predict from one's intention $\stackrel{23}{2}$. Attitudes have a better predictive ability towards intentions than the other two variables. The attitude of managers in this study has a positive and significant influence on intentions in implementing the balanced scorecard. The results of the same study were also said that attitude variables had a positive and significant effect on the intention to implement Government
Regulation No. 71 of $2010 \stackrel{24}{2}$. Behavior in the theory of planned behavior explained that attitudes refer to how individuals are influenced by learning and experience, evaluating certain behaviors to be pleasant or unpleasant and acknowledge and respond to consistently defined behaviors. Intention that arises in an individual to behave directly is influenced by values. Some factors that influence attitudes include past behavior, profit and risk values, planning, environmental influences. If managers believe that the behavior of implementing the balanced scorecard will lead to positive results, they will maintain a good attitude towards the behavior, but on the contrary if the manager believes that doing so with negative results will maintain a bad attitude.

Subjective norms themselves are assumed to be beliefs of individuals or groups who will approve or disagree with a behavior that is influenced by others and the environment ${ }^{25}$. The results of similar studies were also states that there is no significant effect of subjective norm variables on intention. Thus, the findings of this study are in accordance with the findings empirical in the previous chapter which states that if subjective norms are higher, then will increase the intention of someone to behave obediently. Previous research has also shown that subjective norms are the strongest influence on the formation of the intentions of an individual ${ }^{26}$.

Support and commitment from leaders play a strong role in shaping subjective norms and normative beliefs so that they can be a motivation for the people they lead to act in accordance with their normative expectations 27 . This is in accordance with what was stated by Ajzen which states that if an individual believes in what is the norm of the group, then he will obey and shape behavior according to his group. In this study, the measurement of subjective norms is related to interpersonal influences that come from leaders and coworkers. Wiersman identifies several factors that motivate managers in western countries to adopt BSC including $\stackrel{28}{ }$ :

1. Obedience to New Forms of Information The level of openness to new types of information influences managerial decisions about the use of BSC. Managers who receive information from sources of new information systems will most likely use BSC. This is at least in part based on individual personality traits such as innovativeness. Managers who are more innovative and open to new ideas are more likely to use information from a new Management Information System (SIM) such as the BSC $^{29}$. Organizations with innovative cultures will quickly adopt new SIMs, 
because at the organizational level, innovative managers will do so actively promoting the adoption or modification of existing management control systems.

2. Control System Management control systems are defined as a common system in an organization where managers in organizations influence other organizational members to implement organizational strategies ${ }^{30}$. The BSC is a well-functioning management control tool as a process control mechanism and outcome control mechanism ${ }^{31}$. Employees are influenced by organizational controls and systems which include control of actions as well as personal or cultural controls. Action control can be understood as rules and procedures to guide employee actions. Personal and cultural controls emphasize that the right people are employed and a good culture can be accepted in the organization. Organizational control mechanisms need to be designed to coordinate with each other in order to function.

3. Evaluation style. The way managers evaluate subordinates can also be a motivation for them to use the $\mathrm{BSC}^{32}$. Research found that the way managers evaluate subordinates influences the extent to which they use management control systems. Armesh, Salarzehi, \& Kord show how managers can evaluate their subordinates by using four evaluative styles, namely budget constraint (BC), profit conscious (PC), non-accounting (NA) and budget-profit (BP) that expected to influence their decisions regarding the application of the $\mathrm{BSC}^{33}$.

Some social factors that can shape one's normative beliefs include education, income, environmental care, experience and knowledge ${ }^{34}$. The relevant social environment to be able to carry out the concept of balanced scorecard may be because the social environment is fully aware of the perceived benefits of implementing the concept.

Perceptions of behavioral control as functions based on beliefs are called control beliefs, namely individual beliefs about the presence or absence of factors that support or hinder an individual to perform a behavior. This belief is based on past experience and information from other people's experiences. Ajzen explains that the more individuals perceive many supporting factors and the fewer inhibiting factors to conduct a behavior, the more control they feel over the behavior and vice versa, if fewer individuals feel the supporting factors and many inhibiting factors to do behavior, then individuals tend to perceive themselves difficult to carry out these behaviors.

The results of Arismunandar's research shows that the decreasing perceived behavioral control is decreasing someone, then the person's intention to behave increases $\frac{35}{}$. Andreanto state that behavioral control is perceived (Perceived Behavioral Control) has motivational implications on intention. Individual who believes that he does not have the resources to carry out certain behaviors, tend not to form strong intentions to carry it out, even though the individual has an attitude nice to the behavior ${ }^{36}$.

\section{CONCLUSION}

Based on research and discussion conclusions can be drawn as follows: The intention of hospital managers in implementing the Balanced Scorecard was influenced by attitudes toward behavior. The intention of the hospital managers in implementing the Balanced Scorecard is influenced by subjective norms. The intention of the hospital managers in implementing the Balanced Scorecard is influenced by behavioral control. The intention of hospital managers in implementing the Balanced Scorecard was influenced by attitudes toward behavior, subjective norms, and behavioral control.

Suggestion, based on the research the intentions manager influenced by attitude, subjective norm and behaviour control. The researcher recommends creating an environment based on trust and the spirit of cooperation between directors, managers, and staff and employees to instill the intention and motivation to implement the balanced scorecard. One of the steps that can be taken to build control trust from subordinates or staff is by conducting training and socialization in stages and continuously which is expected to increase a more comprehensive understanding of the concept of balanced scorecard.

\section{REFERENCE}

1. Aji, A. P., \& Tjahjono, H. K. (2016). Pemahaman Implementasi Rencana Strategi Bisnis RS PKU Muhammadiyah Petanahan, 5(2), 1-16.

2. Speziale, G. (2015). Strategic management of a healthcare organization: engagement, behavioural indicators, and clinical performance, 17, 3-7.

3. You, L., Aiken, L. H., Sloane, D. M., Liu, K., He, G., $\mathrm{Hu}$, Y.,Shang, S. (2013). International Journal of Nursing Studies Hospital nursing, care quality, and patient satisfaction : Cross-sectional surveys of nurses and patients in hospitals in China and Europe. 
International Journal of Nursing Studies, 50(2), 154 161.

4. Rui, W. (2016). Determinant Factors influencing the use of Balanced Scorecard in China.

5. Isfahani, A. M., Hamid, S., \& Hosseini, K. (2016). Management as a Key Stone of Strategy Implementation Process, 5(1), 31-37.

6. Enteshari, E., Abadi, N., Karbasi, A., \& Soltani, I. (2012). Strategic Planning Model Formulation Based on Balanced Score Card: A Case Study. International Journal of Academic Research in Business and Social Sciences, 2(7), 2222-6990.

7. Behrouzi, F. (2014). Applications of the balanced scorecard for strategic management and performance measurement in the health sector, 208-217.

8. Lueg, R., \& Vu, L. (2015). Success Factors in Balanced Scorecard Implementations - a Literature Review. Management Revu, 26(4), 306-327. https://doi.org/10.1688/mrev-2015-04-Lueg

9. Tjahjono, H.K. (2004). Budaya Organisasi dan Balanced Scorecard: Dimensi Teori dan Praktik. UPFE UMY

10. Beatriz, M., Sanchez, G., Maria, A., Pires, M., \& Broccardo, L. (2017). The use and design of the BSC in the health care sector: A systematic literature review for Italy , 1-25.

11. Aidemark and Funck. (2012). Measurement and health care management ", 253-276.

12. Schröder, T., Stewart, T. C., \& Thagard, P. (2014). Cognitive Science ., 1-47.

13. Wayan, N., Suprapti, S., Nyoman, N., \& Yasa, K. (2015). Aplikasi Teori Planned Behavior dalam Membangkitkan Niat Berwirausaha bagi Mahasiswa Ekonomi. Program Magister Manajemen Universitas Udayana ( Unud ), Denpasar, Bali Indonesia Fakultas Ekonomi dan Bisnis, Univer, 12, 895-920.

14. Ajzen, I. (2015). Consumer attitudes and behavior : the theory of planned behavior applied to food consumption decisions. Rivivista di Economia Agraria, 121-138.

15. Seyal, A. H., \& Turner, R. (2012). A study of executives' use of biometrics: an application of theory of planned behaviour. Behaviour \& Information Technology, 32(12), 1-15.

16. Etezady, N. (2016). Subjective Norm and Measuring Its Impact on Information Security Behavioral Intention in, 1-13

17. Huda, N., Rini, N., Mardoni, Y., \& Putra, P. (2012). The Analysis of Attitudes, Subjective Norms , and
Behavioral Control on Muzakki's Intention to Pay Zakah. International Journal of Business and Social Science, 3(22), 271-279.

18. Widiastuti, H., Palupi, M., \& Tjahjono, K. H. (2016). An Application of the Theory of Planned Behavior in Describing top Manager's Intention to Employ People with Disabilities in Indonesia, 1680-1688.

19. Greaves, M., Zibarras, L. D., \& Stride, C. (2013). Using the theory of planned behavior to explore environmental behavioral intentions in the workplace. Journal of Environmental Psychology, 34, 109-120.

20. Icek Ajzen. (2002). Perceived Behavioral Control, Self-Efficacy, Locus of Control, and the Theory of Planned Behavior1. Journal of Applied Social Psychology, 80(6), 2918-2940.

21. Kautonen, T., van Gelderen, M., \& Fink, M. (2015). Robustness of the Theory of Planned Behavior in Predicting Entrepreneurial Intentions and Actions. Entrepreneurship Theory and Practice, 39(3), 655674.

22. Bejtkovsky, J. (2016). The Employees of Baby Boomers Generation, Generation X, Generation Y and Generation Z in Selected Czech Corporations as Conceivers of Development and Competitiveness in their Corporation. Journal of Competitiveness, 8(4), 105-123.

23. Shaheen, M., Cheng, B. L., \& Lee, H. S. (2015). A Study of E-Shopping Intention In Malaysia: The Influence Of Generation X \& Y. Australian Journal of Basic and Applied Sciences, 6(8), 28-35.

24. Pontoh, G. T. (2014). Teori Planned Behavior dan Readiness for Change dalam Mempredikasi Niat Implementasi Peraturan. Tesis. Universitas Udayana.

25. Knabe, A. (2012). Applying Ajzen's Theory of Planned Behavior to a Study of Online Course Adoption in Public Relations Education. Faculty of the Graduate School, Doctor of, 256-269.

26. Özülkü, E. S. (2018). German Generation Y ' s Purchase Intention towards Packaging-Free Products : A TPB Approach, Journal of Bisnis. 165-183.

27. Hatak, I., Harms, R., \& Fink, M. (2015). Age, job identification, and entrepreneurial intention. Journal of Managerial Psychology, 30(1), 38-53.

28. Wiersma, E. (2014). For which purposes do managers use Balanced Scorecards? An empirical study, 20, 239-251.

29. Rui, W. (2016). Determinant Factors influencing the use of Balanced Scorecard in China. 
30. Wiersma, E. (2014). For which purposes do managers use Balanced Scorecards? An empirical study, 20, 239-251.

31. Qehaja, A. B., Kutllovci, E., \& Pula, J. S. (2017). Strategic management tools and techniques usage: A qualitative review. Acta Universitatis Agriculturae et Silviculturae Mendelianae Brunensis, 65(2), 585-600.

32. Khatoon, S., \& Farooq, A. (2014). Balanced Scorecard to Measure Organizational Performance: A Case Based Study. The International Journal Of Business \& Management, 2(9), 2321-8916.

33. Armesh, H., Salarzehi, H., \& Kord, B. (2013). Management Control System. Interdisciplinary Journal of Contemporary Research in Business, 2(6), 193-206.

34. Donald, I. J., Cooper, S. R., \& Conchie, S. M. (2014). An extended theory of planned behavior model of the psychological factors affecting commuters' transport mode use. Journal of Environmental Psychology. 472490

35. Arismunandar, Budi Susetyo. 2001. Analisis Variabel Yang Berpengaruh terhadap Niat Beli Konsumen Audio Mobil, Tesis, Program Magister Manajemen Universitas Diponegoro, Semarang.

36. Andreanto, Anas. 2013. Aplikasi Teori perilaku Terencana ; Niat Melakukan Physical Exercise (latihan Fisik) Pada Remaja di Surabaya, Jurnal Ilmiah Mahasiswa Universitas Surabaya, Vol II, No 2, pp. 112 